\title{
Strategic Planning for Promoting Energy Saving Awareness at Student Residential Colleges Universiti Teknologi Malaysia
}

\author{
Imanurezeki Mohamad* ${ }^{1}$, Nurul Adzura Ismail ${ }^{1}$, Nur Fadilah Darmansah ${ }^{2}$, \\ Azlyana Adnan ${ }^{3}$, Noor Mala Ibrahim ${ }^{4}$ \\ ${ }^{1}$ Energy Manager, Office of Asset and Development, Universiti Teknologi Malaysia \\ ${ }^{2}$ Lecturer, Faculty of Engineering, Universiti Teknologi Malaysia, Malaysia \\ ${ }^{3}$ Master Student, Faculty of Education, Universiti Teknologi Malaysia, Malaysia \\ ${ }^{4}$ Lecturer, Language Academy, Faculy of Sciences and Humanities, Universiti Teknologi Malaysia, Malaysia \\ *Corresponding Author Email: imanurezeki@utm.my
}

\begin{abstract}
Energy management issues are interconnected with estimated energy consumption reductions, management of building energy system and decision approaching sustainable development planning. Systematic energy management is important for campus sustainability objectives due to the escalation of energy costs and decreasing budgets for energy management. Student residential colleges are an important measurement variable for university sustainable development goals and should be seen as core contributors to the reduction of energy consumption. The objective of the study is to measure the level of energy consumption and energy-saving awareness among students at residential colleges, Universiti Teknologi Malaysia (UTM), to improve the management facilities and services and at the same time to identify the aspects of building energy efficiency for potential energy saving. Ten student residential colleges in UTM were investigated. Data were gathered through a self-administered survey, and area and facility observations. Statistical Package for the Social Sciences (SPSS) version 16.0 was used for analysis. Findings reveal that building energy consumption reanalysis and demographic overview provide a conceptual framework to understand and manage basic parameters concerning various factors that reflected changing trends of energy consumption over the years. The proposed framework will lead to the adoption of other building energy efficiency and energy-saving practices. Keywords: Sustainablity, Energy Efficiency, Energy Savings, Strategic Management.
\end{abstract}

\section{INTRODUCTION}

The perspectives of energy management are driven by the remarkable increase in economic development, increasing population size, and rising standards of living. The main objective is to reduce energy costs under a significant area of various sectors such as buildings and a shift towards an energy-efficient building. Energy management issues are interconnected with estimated energy consumption reductions, management of building energy system and decision approaching sustainable development planning. In this context, previous researches reframe energy management by the existence to address the issues of higher energy consumption and building energy-wasting and [1; 2]. As a consequence, other research has emphasized on systematic energy management approach to improve building energy efficiency based on energy consumption benchmarking [3], building energy refurbishment [4] and implementing energy management system [5;6]. Furthermore, systematic energy management concerning the various building types, operations, and facilities become more complex and multidimensional when related to other factors such as changing trends over the years, occupants' lifestyles and behaviours and stakeholder profitability interest.
In particular, strategic energy management becomes an integral part of Malaysian Higher Educational Institutions (MHEIs) to provide a high-quality education with sustainable environments based on smart energy management (SEM) $[7 ; 8 ; 9]$. The mainstreaming of SEM in MHEIs is promoted and integrated with different building functions and facilities management, green and resilient infrastructure, and waste management to reduce carbon emissions and achieve sustainable development goals. However, in accordance with the rapid growth of the university population and expansion of campus that leads to intensified and unsustainable demand for energy, it is necessary to establish energy saving practices on campus [10]. At the same time, the issue of campus sustainability has been subject to intensifying energy saving due to the rapid escalation of energy costs and decreasing allocation budgets for energy management. According to other studies, implementations of strategic energy management approach at university campus are expected with at least 5 to 20 percent of annual energy saving [5; 11]. The percentage of energy saving at the university level maybe difficult to obtain due to the increasing student enrolment and continued expansion of university properties while fulfilling the needs to provide a conducive atmosphere for student learning and living. 
According to Abdulrazak and Fauziah [12], the campus physical development planning in many Malaysia universities does not satisfy the needs of students and less sensitive to change. Yen et al. [8] highlight that the lack of awareness among students and inefficient use of energy by the universities have contributed to energy wastage. Student residential colleges serve as an important measurement variable for university sustainable development goals and should be seen as a core strategy for reducing energy consumption. It is found that students' lifestyles at residential colleges are the essential issue of energy wastage which is mainly governed by lack of energy saving awareness.

Since 2013, University Teknologi Malaysia (UTM) with the collaboration of the Office of Assets and Development (OAD), UTM has to embrace the general saving awareness program under UTM Campus Sustainability Policy 2011. As reported by Zakaria et al. [13] UTM energy conservation strategy can reduce total campus energy consumption by 30 percent or more. According to Shuhana et al. [14], the first attempt to develop awareness and change the perception of energy saving among students is to estimate the energy consumption through their behavioural viewpoints and understand the patterns of energy consumption among them. This will assist the university facility or energy management team in estimating current and future energy consumption and potential energy saving [15]. Several studies identified that the importance of energy saving awareness strategy will make students more knowledgeable on environmental matters, thus the possibility of shaping their attitudes and behaviors [16] towards energy saving.

\section{OBJECTIVES}

The UTM Energy Saving Awareness Program is currently a pilot program initiated in 10 student residential colleges of the university as part of campus sustainability program. It will be expanded campus-wide in the near future. The research was conducted to improve the management facilities and services and to identify the aspects of building energy efficiency for potential energy saving at UTM. The main purpose of the research is to measure the level of energy consumption and energy saving awareness among students at UTM residential colleges. To develop the strategic planning for energy awareness programs, this study will focus on the development of a better understanding of energy consumption across the residential colleges and the search for options to reduce energy wastage which therefore, control the energy demand and associated costs. The main energy use is electrical, therefore throughout this article; the energy consumption will refer to the total of electricity use. For decision making context, this study will highlight issues in occupants' behaviour rather and other related factors that are not directly investigated.

\section{METHODOLOGY / MATERIALS}

Universiti Teknologi Malaysia (UTM) campus is located in Johor Bahru in the Southern part of Peninsular Malaysia with temperate climate and a monthly temperature mean ranges from $22^{\circ} \mathrm{C}$ to $32^{\circ} \mathrm{C}$ throughout the year. UTM main campus consists of 624 buildings covering 14 faculties, 10 residential colleges and 9 administration and management buildings. The total build up area is $1,099,800 \mathrm{~m}^{2}$. Figure 1 illustrates the general view of built up area of student residential colleges under study. Based on the statistics in 2018 , the total population has been 17, 000 with almost 12 , 500 staying at residential colleges. The annual electricity consumption for the university last year exceeded 32 million $\mathrm{kWh}$ and 10 million $\mathrm{kWh}$ is from the residential colleges. The total energy costs for the UTM campus are over RM 20 million annually and the total annual average energy costs is approximately RM 3 million for the 10 residential colleges.

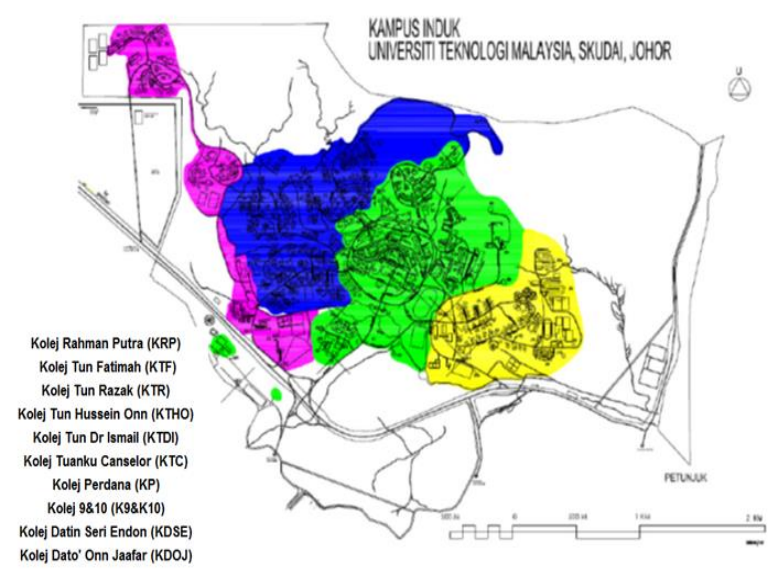

Figure 1 Student Residential Colleges, Universiti Teknologi Malaysia (UTM)

This study is divided into several parts from data compilation, areas and facilities observations, and selfadministered surveys. The observation and building energy benchmarking were carried out consecutively for 15 days. The self-administered survey conducted consists of semistructured open-ended questions from respondents from each residential college. Energy consumption and building data provided by the Office of Assets and Development (OAD) of UTM. The energy consumption data is collected 
from the average daily kilowatt-hour, and the average kilowatt hour per gross square footage per day was calculated along with the average $\mathrm{kWh}$ per month. This study used SPSS (Statistical Package for the Social Sciences (SPSS) version 16.0) for analysis in a different format. Data analyses were mainly descriptive statistics and line graphs and bar charts related to different measured were generated.

The reliability coefficient is a measure of reliability where higher coefficients lead to better reliability. For this study, Cronbach Alpha coefficients were used. It is usually used as a measure of depth consistency or reliability of psychometric tests for sample questionnaire scores. The Cronbach Alpha reliability test was conducted using SPSS. The Cronbach Alpha coefficient is often used as an indicator of the reliability of the questionnaire, which indicates that the subjects exhibited a similar trend throughout the questionnaire. Izran [17] and Cong [18] defined that reliability estimates are acceptable if the Cronbach Alpha coefficient is higher than 0.70. Table 1 illustrates the level of reliability on a scale of 0 to 1 .
Table 1 Cronbach Alpha Reliabilty Coefficient Range (Cronbach, 1951)

\begin{tabular}{ll}
\hline Cronbach's Alpha Score & Level of Reliability \\
\hline$\alpha \geq 0.9$ & Very Reliable \\
$0.7 \leq \alpha<0.9$ & Rather Reliable \\
$0.6 \leq \alpha<0.7$ & Quite Reliable \\
$0.5 \leq \alpha<0.6$ & Reliable \\
$\alpha<0.5$ & Very Reliable \\
\hline
\end{tabular}

\section{RESULTS AND DISCUSSIONS}

\subsection{Demographic Analysis}

The characteristics of current students at each UTM residential college give information on their gender and age, continent of their home country and levels of study as shown in Table 2. The demographic analysis is important as it gives a better understanding of the data retrieved. Table 2 also provides general information based on energy consumption structure that differs across colleges. In fact, there is no similarity between the colleges and energy consumption per occupant. While there are several factors that reflect energy consumption behaviours [19], for the purpose of this study, only several selected energy consumption behaviour factors from the energy culture framework were included.

Table 2 Demographic Profile of UTM Residential College Students.

\begin{tabular}{|c|c|c|c|c|c|c|c|c|c|c|c|}
\hline Variables & Criteria & KRP & KTF & KTR & КTHO & KTDI & KTC & KP & K9\&10 & KDSE & KDOJ \\
\hline \multirow{3}{*}{ Gender } & Male & 641 & 0 & 838 & 791 & 756 & 827 & 245 & 872 & 423 & 760 \\
\hline & Female & 520 & 1127 & 557 & 587 & 816 & 362 & 589 & 1279 & 556 & 0 \\
\hline & TOTAL & 1161 & 1127 & 1395 & 1378 & 1572 & 1189 & 834 & 2151 & 979 & 760 \\
\hline \multirow{4}{*}{ Age (\%) } & 18 - 24 & 65 & 55 & 85 & 85 & 90 & 45 & 55 & 65 & 36 & 10 \\
\hline & $25-34$ & 35 & 45 & 15 & 15 & 10 & 45 & 20 & 35 & 30 & 45 \\
\hline & $35-44$ & 0 & 0 & 0 & 0 & 0 & 10 & 20 & 0 & 30 & 45 \\
\hline & $45-54$ & 0 & 0 & 0 & 0 & 0 & 0 & 5 & 0 & 4 & 5 \\
\hline \multirow{3}{*}{$\begin{array}{l}\text { Continent / } \\
\text { Country }(\%)\end{array}$} & Malaysia & 90 & 90 & 95 & 95 & 95 & 70 & 60 & 90 & 75 & 60 \\
\hline & Asia & 10 & 10 & 5 & 5 & 5 & 20 & 20 & 10 & 15 & 20 \\
\hline & Africa & 0 & 0 & 0 & 0 & 0 & 5 & 10 & 0 & 5 & 10 \\
\hline \multirow{3}{*}{$\begin{array}{l}\text { Level of } \\
\text { Study }(\%)\end{array}$} & Undergraduate & 95 & 90 & 95 & 95 & 95 & 75 & 60 & 95 & 0 & 0 \\
\hline & Masters & 3 & 5 & 3 & 3 & 3 & 15 & 20 & 5 & 60 & 60 \\
\hline & PhD & 2 & 5 & 2 & 2 & 2 & 10 & 20 & 0 & 40 & 40 \\
\hline
\end{tabular}




\subsection{Performance of Energy Consumption}

Detailed annual energy consumption for the year 2015 to 2018 of all residential colleges present in the UTM campus is shown in Figure 2. The fluctuation of the energy consumption was relatively significant with the student to enroll and level of study. The major end-uses for energy consumption in student residential colleges are computer application (30\%), facilities such as lighting and fan (45\%) and several others (as illustrated in Figure 3). The study has also been conducted on energy cost consumption structure for four years which shows a decreasing trend in the energy cost consumption every year (see Figure 4). The reduction of energy consumption cost is due to the implementation of an energy efficiency program at the college. As shown in Figure 5, consumption/student for all student's residential college mostly increases with an increase in time.

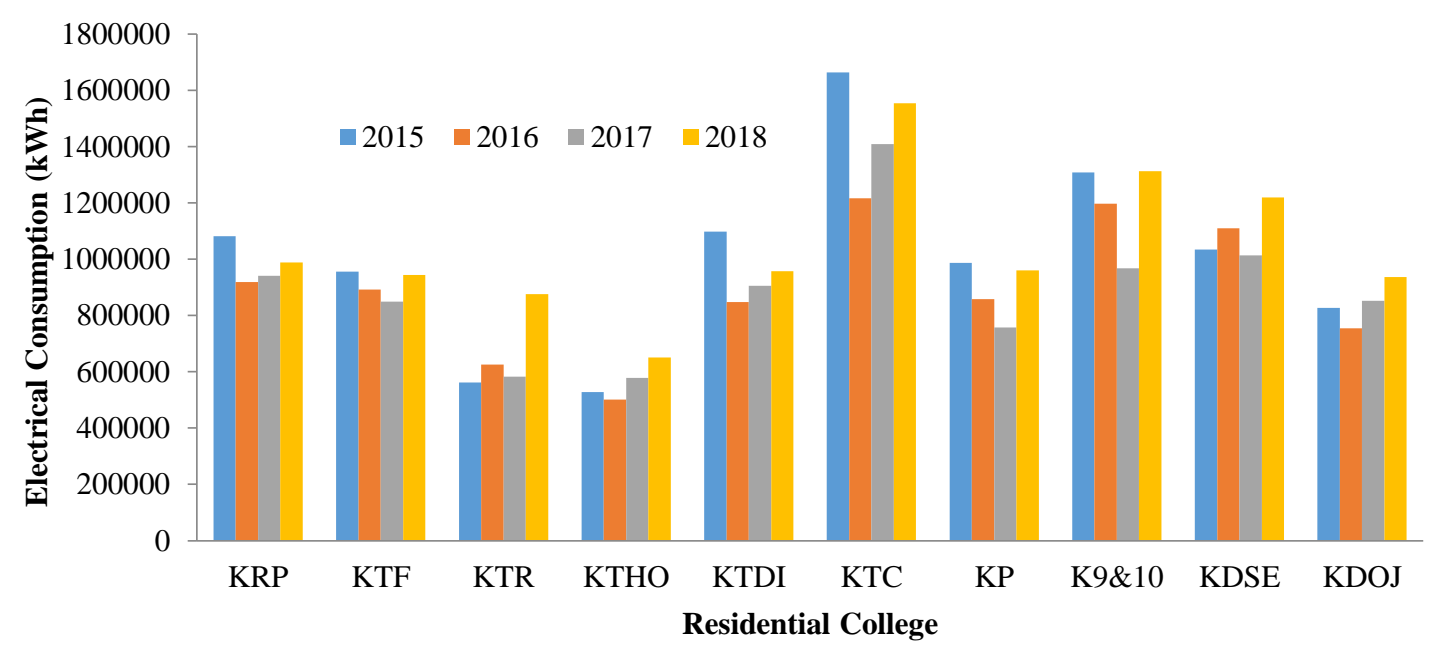

Figure 2 Annual Energy Consumption of UTM Residential College for 2015 - 2018

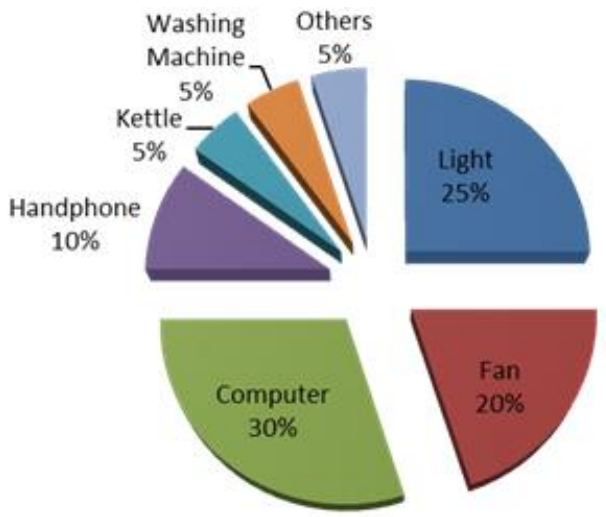

Figure 3 Estimated of End-Uses of Energy Consumption for UTM Residential College 


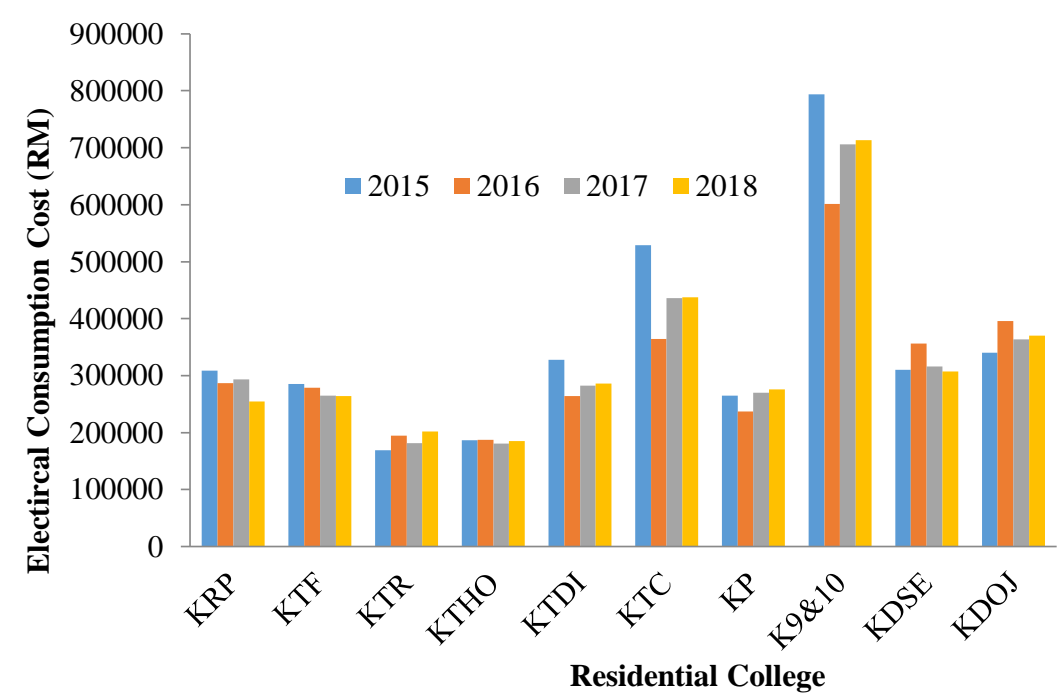

Figure 4 Annual Energy Consumption Cost of UTM Residential College for 2015 - 2018

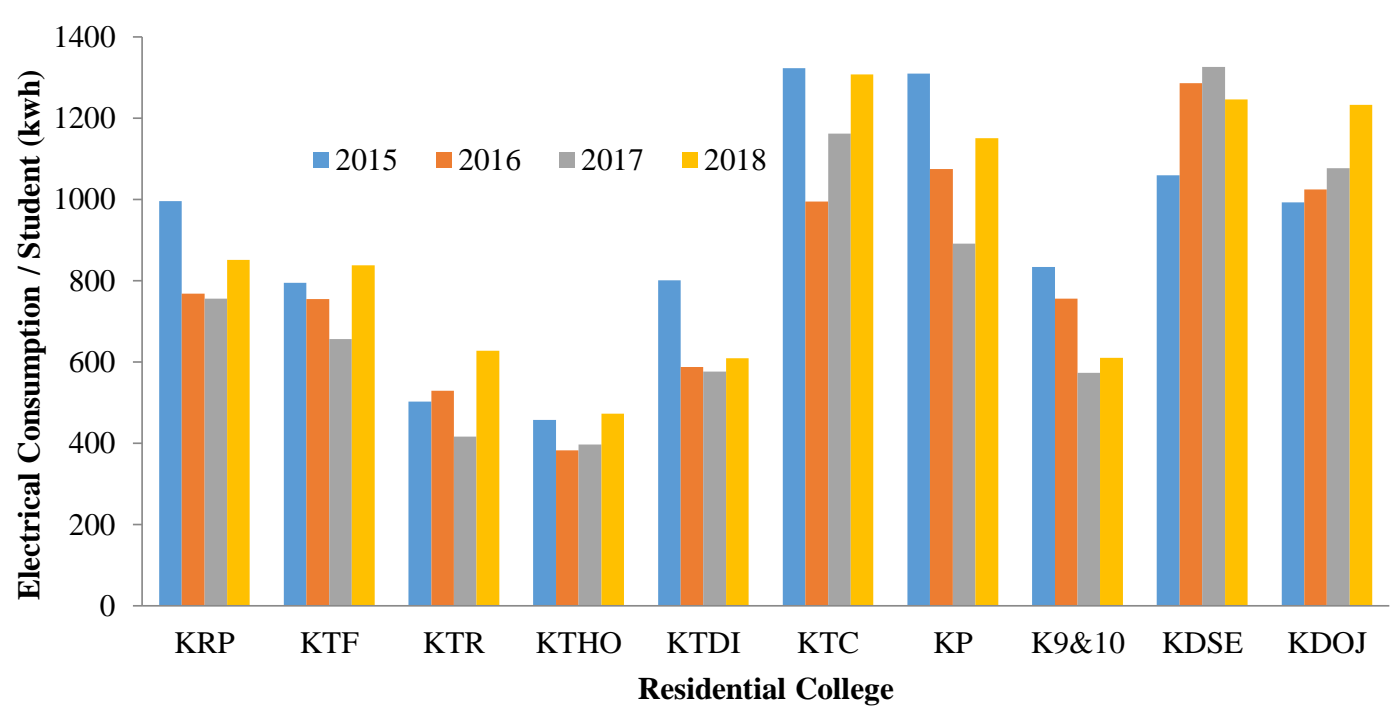

Figure 5 Annual Energy Consumption/Student in UTM Residential College for 2015 - 2018

The term Energy Efficiency Index (EEI) is used in this study to show the performance of energy consumption at the residential colleges elaborated as $\mathrm{kWh} / \mathrm{m}^{2} /$ year. Four years (2015-2018) of energy consumption data that were collected and analysed, and the total floor area calculated from the UTM building design study were used for this study.

The performance of electricity consumption in each residential college was calculated based on estimated energy intensity by [20], EEI in $\mathrm{kWh} / \mathrm{m}^{2}$, using the following equation:

$$
E E I=\frac{A E C}{T F A}
$$

where, AEC is annual energy consumption $(\mathrm{kWh})$ and TFA is the total floor area $\left(\mathrm{m}^{2}\right)$.

According to Iwaro and Mwasha [21], energy usage in residential colleges is typically 10-20 times lower than that of office buildings. Therefore, the electricity use in residential colleges in Malaysia amounts to approximately 10 to $25 \mathrm{kWh} / \mathrm{m}^{2} /$ year if the electricity use in office buildings in Malaysia is in the range of 200 to 250 $\mathrm{kWh} / \mathrm{m}^{2} /$ year $[22 ; 23]$

The comparison of energy consumption/overall built-up area shows in Figure 6 illustrated a very strong correlation, which shows that an increase in per capita built space will increase the per capita energy usage. 


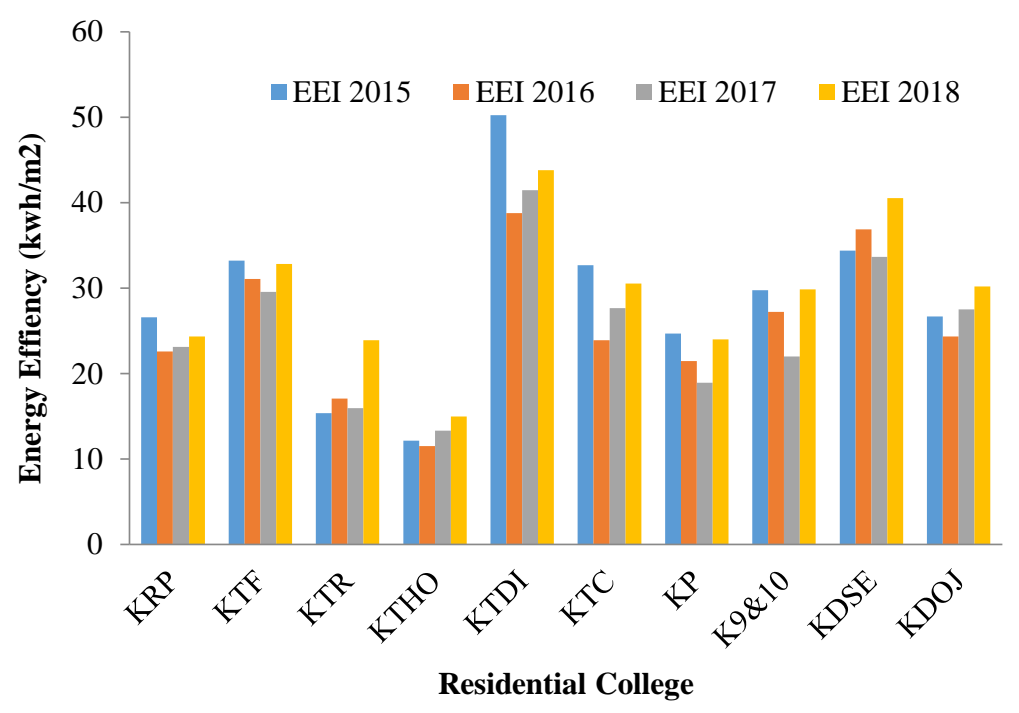

Figure 6 Energy Efficiency Index in UTM Residential College for 2015 - 2018

\subsection{Energy Consumption Factor Analysis}

As illustrated in Figure 7, the non-technical factor is the most critical. The behavior of occupants plays a high role in high and low building energy consumption [24; 25; 26]. Figure 7 also shows that the awareness of energy saving among occupants of a residential college is still low.

The result of the reliability test is 0.719 as shown in Table 3. This indicates that the questionnaire is reliable and suitable for use.

The technical factors are out of the scope of this article objective. The objective function of promoting energy saving only focused on occupant behaviour. Therefore, the results of this study can be compared with similar building categories. In addition, there are several challenges in conducting technical factor in this study, as the residential buildings system associated with the different energy and multiple parameters findings key parameters for control the performance energy consumption analysis stage.

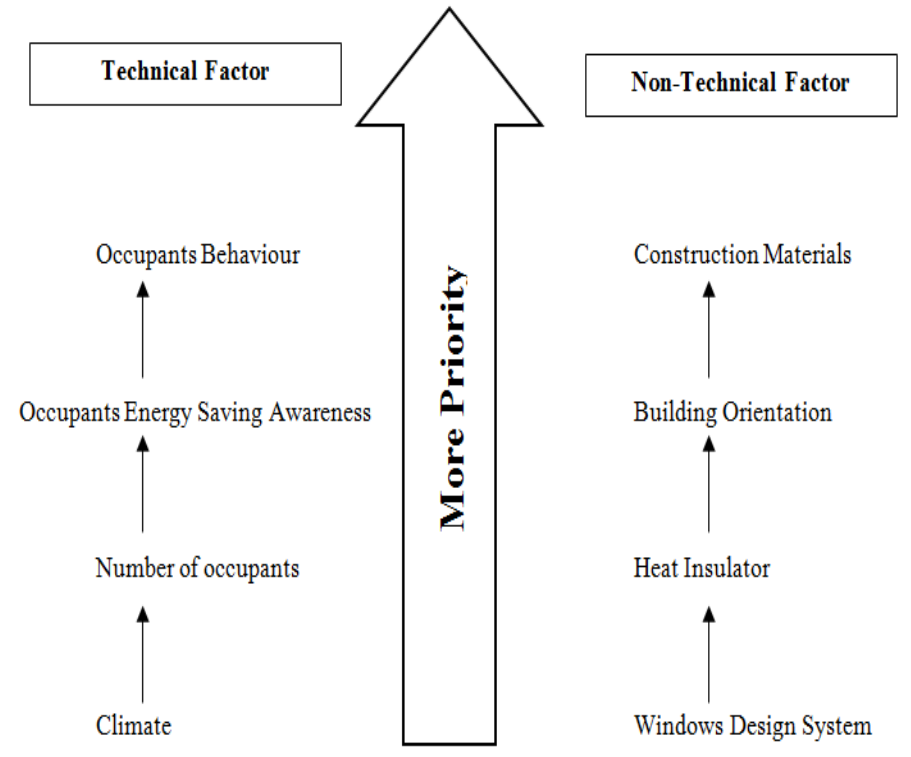

Figure 7 Influent Factors of Building Energy Consumption. 
Table 3 Cronbach's Alpha Reliabilty Range Analysis for High Energy Consumption Factor for UTM Student Residential Colleges

\begin{tabular}{|c|c|c|}
\hline & $\begin{array}{l}\text { Factor of High Energy } \\
\text { Consumption Factor }\end{array}$ & $\begin{array}{l}\text { "Cronbach's Alpha if } \\
\text { Item Deleted }\end{array}$ \\
\hline & Number of occupants & 0.719 \\
\hline & Climate & 0.687 \\
\hline \multirow{4}{*}{ 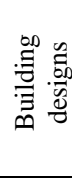 } & Building Size and Shape & 0.693 \\
\hline & Building Orientation & 0.668 \\
\hline & Windows Design System & 0.691 \\
\hline & Construction Materials & 0.707 \\
\hline & Heat Insulator & 0.676 \\
\hline & Electrical Equipments & 0.692 \\
\hline & Occupants Behaviour & 0.726 \\
\hline & $\begin{array}{lll}\text { Occupants } & \text { Energy } & \text { Saving } \\
\text { Awareness } & & \\
\end{array}$ & 0.708 \\
\hline & Cronbach Alpha Result & 0.719 \\
\hline
\end{tabular}

\subsection{Proposed Strategic Planning for Energy Saving Awareness}

Strategic planning for energy saving awareness programs needs a clear system from data collection, observation, analysis, validation and decision making. The system flow as illustrated in Figure 8 can be applied to address the energy consumption issues and the need for an energy awareness campaign.

Other efforts for conducting energy saving awareness program must be implemented with reliable data over the building operation and occupants behaviour change as an effort for reducing energy consumption.

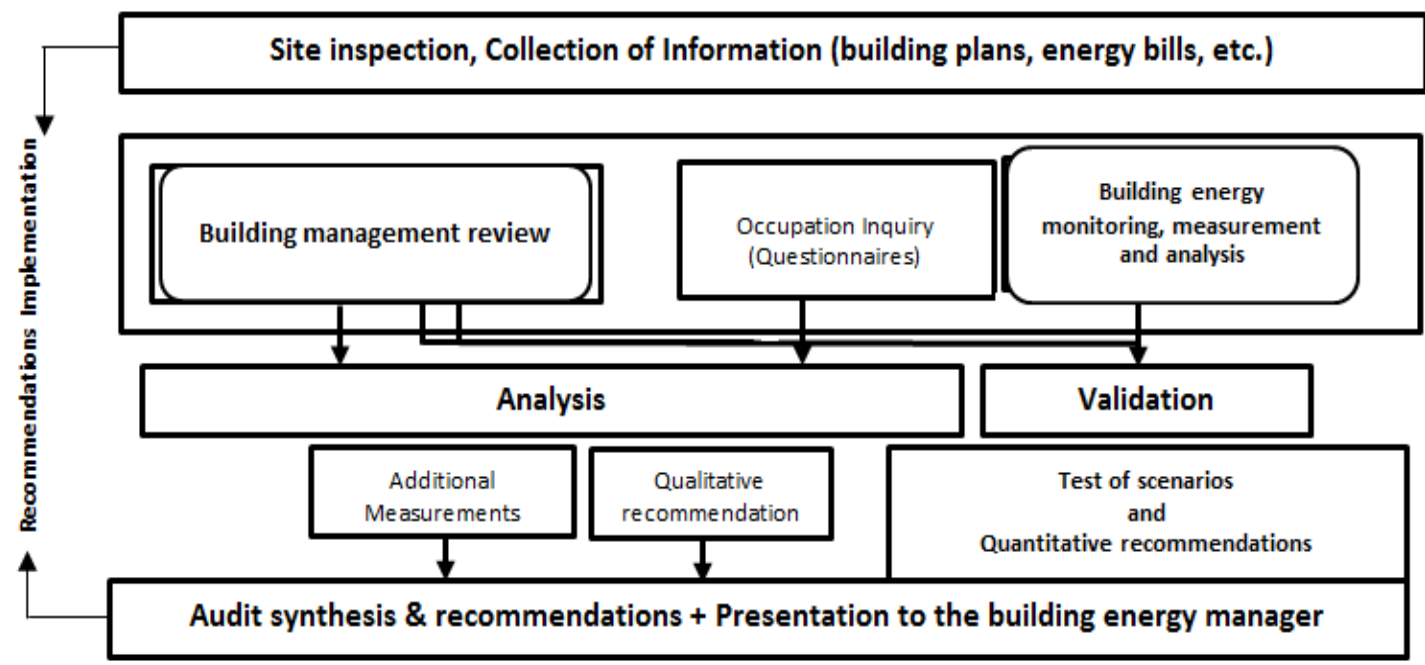

Figure 8 Strategic Management for Energy Awareness Decision Making Process

\section{CONCLUSION}

This paper provides a step to implement strategic planning to promote energy awareness program. An analysis of building energy consumption and demographic overview will provide a conceptual framework to understand and manage basic parameters concerning various factors that reflected changing trends of energy consumption over the years and to be extended to other sustainability parameters. The part of this study discussed the development of strategic planning for energy saving awareness among student residential colleges as an important and promising area to be studied. The major aim of this study to measure the level of energy consumption and energy saving awareness showed the fluctuation trends are expected due to the growth of awareness based on diverse variations of student's behaviour and lifestyles, and level of study. However, the extent of energy saving awareness issues is addressed varies from each residential college and this study should be further study to other Malaysian Higher Educational Institutions (MHEIs) for comparable and to assess the extent efforts towards Campus sustainability. The proposed framework will lead to the adoption of others building energy performance and energy saving practices. 


\section{ACKNOWLEDGMENT}

This work was supported by Kolej Tun Fatimah Administration and incontribution with Office of Asset and Development, UTM.

\section{REFERENCES}

[1] Molina-Solana, M., Ros, M. Dolores Ruiz, M., G'omez-Romero, J., and Martin-Bautista, M. J. (2017). Data Science for Building Energy Management:A Review, Renewable and Sustainable Energy Reviews, 70, 598-609.

[2] Grueneich, D. M. (2015). The Next Level of Energy Efficiency: The Five Challenges Ahead. Economics, 2015.

[3] von Kistowski, J., Lange, K - D., Arnold, J. A., Sharma, S., Pais, J., and Block, H., (2018). Measuring and Benchmarking Power Consumption and Energy Efficiency. Proceeding ICPE '18 Companion of the 2018 ACM/SPEC International Conference on Performance Engineering, Berlin, Germany — April 09 - 13, 2018.

[4] Ramos, J. S., Dominguez, S. A., Moreno, M. P., Delgado, M. G., Rodriguez, L. R., and Rios, J. A. T. (2019). Design of the Refurbishment of Historic Buildings with a Cost-Optimal Methodology: A Case Study. Appl. Sci. 2019, 9(15), 3104.

[5] Julaihi, F., Ibrahim, S. H., Baharun, A., Affendi, R., and Nawi, M. N. M. (2017). The Effectiveness of Energy Management System on Energy Efficiency in the Building. AIP Conferrence Proceedings, 1891.

[6] Rocha, P., Siddiqui, A., and Stadler, M. (2015). Improving Energy Efficiency Via Smart Building Energy Management Systems: A Comparison with Policy Measures. Energy and Buildings, 88, 203-213.

[7] Khalil, N., Husin, H. N., and Nawai, A. H. (2012). An Analytical Literature: Strategic Improvement of Sustainable Building Performance Tool for Malaysia's Higher Institutions. Procedia - Social and Behavioral Sciences, 36 ( 2012 ), $306-313$.

[8] Yen, N. S., Shakur, E. S. A., and Wai, C. W. (2010). Energy Conservation Opportunities in Malaysia Universities. Malaysian Journal of Real Estate, 5 (1).

[9] Sapri, M. and Muhammad, S. (2010). Monitoring Energy Performance in Higher Education Buildings for
Sustainable Campus. Malaysian J. Real Estate, 5(1), 125 .

[10] Alshuwaikhat, H. and Abubakar, I. R. (2008). An Integrated Approach to Achieving Campus Sustainability: Assessment of the Current Campus Environmental Management Practices. Journal of Cleaner Production, 16(16),1777-1785.

[11] Hassan., J., Zin, R. M., Majid, M. Z. A., and Balubaid, S. (2014). Building Energy Consumption in Malaysia: An Overview. Jurnal Teknologi, 707 (7), 2180 -3722 .

[12] Abdulrazak, S., and Fauziah. SH. (2014). Sustainable Development: A Malaysian Perspective. Procedia - Social and Behavioral Sciences. 164:237-241.

[13] Zakaria, R., Seng, F. K., and Zin, R. M., (2012). Potential Retrofitting of Existing Campus Buildings to Green Buildings. Applied Mechanics and Materials, 178-181, 42-45.

[14] Shuhana, S., Sulaiman, A. B., Lamit, H., Omar, R., Aziz, N. A., and Noor, M. M. (2007). Kriteria Reka Bentuk Persekitaran Kampus Yang Kondusif Bagi Institusi Pengajian Tinggi Di Malaysia. Universiti Teknologi Malaysia.

[15] Geethanjali, B., Hansa, L.M. \& Daniel, M. (2007). An Optimization of Effective Energy Management as a Tool to Facilitate Managers. In WIT Press. 6170.

[16] Jackson, T. (2005). Motivating Sustainable Consumption; A review of evidence on consumer behaviour and behavioural change" In: A report to the Sustainable Development Research Network as part of the ESRC Sustainable Technologies Programme Centre for Environmental Strategy, University of Surrey, Guildford.

[17] Izran, S. M. (2011). Post Occupancy Evaluation of Building Performance in Malaysia. Doctor Philosophy. Universiti Teknologi Malaysia.

[18] Cong, L. (2014). To Study The Perception of Staffs On Types and Quality of Property Management Training Case Study: Zhuoda Group China . Master of Science. Universiti Teknologi Malaysia.

[19] Stephenson, J., Barton, B., Carrington, G., Gnoth, D., Lawson, R. and Thorsnes, P. (2010). Energy Cultures: A Framework for Understanding Energy Behaviours. Energy Policy, 38(10), 6120-6129.

[20] Saidur, R. (2009). Energy Consumption, Energy Saving, and Emission Analysis in Malaysian Office Buildings. Energy Policy, 37, 4104-4113. 
[21] Xin, H. Z., and Rao, S. P. (2013). Active Energy Conserving Strategies of the Malaysia Energy Commission Diamond Building. Procedia Environmental Sciences, 17, 775 - 784.

[22] Jamaludin, R., Nawi, M. N. M., Bahaudin, A. Y., Mohtar, S., and Tahir, M. Z. (2019). Energy Efficiency of Chancellery Building at Universiti Utara Malaysia. Journal of Advanced Research in Fluid Mechanics and Thermal Sciences, $2289-7879$.

[23] Iwaro, J., and Mwasha, A. (2013). The Impact of Sustainable Building Envelope Design on Building Sustainability using Integrated Performance Model. International Journal of Sustainable Built Environment, $2(2), 153-171$.

[24] Low, S. T., Mohammed, A. H., Wai, C. W., and Alias, B. (2010) The Energy Knowledge and Conservation Behaviour Among Community in University. International University Social Responsibility Conference and Exhibition 2010 (IUSRCE2010), October 5-6, Kuala Lumpur, Malaysia. 65-68.

[25] Hester, N., Li, K., Schramski, J. R., and Crittenden, J. (2012). Dynamic Modeling of Potentially Conflicting Energy Reduction Strategies for Residential Structures in Semi-Arid Climates. Journal of Environmental Management. 97, 148-153.

[26] Hansen, S. J. (2002). Manual for Intelligent Energy Services. Lilburn, Ga.: Fairmont Press. 